\title{
CREATIO EX NIHILO - A GENUINELY PHILOSOPHICAL INSIGHT DERIVED FROM PLATO AND ARISTOTLE? SOME NOTES ON THE TREATISE ON THE HARMONY BETWEEN THE TWO SAGES
}

\author{
BENJAMIN GLEEDE \\ Universität Zürich, Theologisches Seminar Kirchgasse 9, CH-8001 Zürich \\ Email: benjamin.gleede@uni-tuebingen.de
}

\begin{abstract}
The article aims at demonstrating that in attributing the creatio ex nihilo to both Plato and Aristotle as their unanimous philosophical conviction the Treatise on the Harmony between the Two Sages deeply depends upon the Neoplatonic reading of those two philosophers. The main obstacles for such a view in the works of the two sages are Plato's assumption of a precosmic chaos in the Timaeus and Aristotle's denial of any efficient causality to the unmoved mover in the Metaphysics. Both of these points had been, however, done away with by the Neoplatonist commentators already, especially by Ammonius in his lost treatise on efficient and final causality in Aristotle the use of which in the Harmony is shown by a comparison with Simplicius. Christian and Muslim readers just had to transfer those arguments and hermeneutical techniques into an anti-eternalist context in order to make the two philosophers agree with one of the basic tenents of their face, a hermeneutical technique considerably different from the one employed by al-Fārābì in his exposition of Plato's and Aristotle's philosophy which is compared to the Harmony in a briefly sketched concluding section.
\end{abstract}

Résumé. L'article vise à montrer que le Traité sur l'harmonie des deux sages, en attribuant la creatio ex nihilo à Platon et Aristote comme conviction philosophique commune, dépend profondément de la lecture néoplatonicienne de ces deux philosophes. Les obstacles principaux à une telle attribution dans les œuvres des deux sages sont, dans le Timée de Platon, l'affirmation d'un chaos précosmique et, dans la Métaphysique d'Aristote, la négation d'une causalité efficiente du premier moteur immobile. L'interprétation néoplatonicienne avait toutefois éliminé chacune de ces affirmations de la doctrine des deux maîtres, comme le montre en particulier le traité d'Ammonius sur la causalité finale et efficiente chez Aristote. Or, on peut montrer, par une comparaison avec Simplicius, que l'Harmonie faisait usage de ce traité. Les philosophes chrétiens et musulmans avaient ainsi la possibilité d'employer les mêmes arguments et méthodes herméneutiques pour établir une concordance entre les deux principales autorités philosophiques d'une part et une de leurs plus importantes convictions religieuses d'autre part - une herméneutique qui diffère considérablement de la méthode appliquée par al-Fārābī dans sa propre exposition des philosophies de Platon et d'Aristote, comme le montre, dans la conclusion de l'article, la brève comparaison avec l'Harmonie.

The history of western philosophy, at least from antiquity to the renaissance age, was a history of understanding, interpretating, 
misunderstanding and criticizing the two outstanding figures who emerged shortly after its beginning and became almost canonical classics shortly after their death: Plato and Aristotle. Their mutual agreement or disagreement was not only a core-topic in the debates between the many different philosophical schools of the Hellenistic era, but was to become a crucial issue in defending the scientific character of philosophy as a whole from Antiochus of Ascalon onwards, ${ }^{1}$ especially in later Neoplatonism, when 'pagan' philosophical science had to struggle against the intellectual and political attacks of the Christian majority. How can the task represented by this tradition, the rational quest for fundamental, metaphysical knowledge, seem promising or even possible, if the two reference-figures at its very beginning, Plato and Aristotle, are actually in disagreement with each other on the most important relevant topics, like the nature of the first principle, the relationship between soul and body or the beginning of the world? This was the question equally to be faced by the Greek philosophers of late antiquity and the Arabic ones of the Middle ages, as we learn most prominently from texts like the one this study is devoted to: the treatise On the Harmony between the Two Sages, ${ }^{2}$ traditionally attributed to al-Fārābī. ${ }^{3}$ In this treatise, the author starts off by attacking the quarrelsome masses and their obsession for constructing logical, political, ethical, physical and metaphysical differences between the two great sages ${ }^{4}$ an obsession which, as he tries to show throughout the entire text, is only based on the lack of proper hermeneutics. This hermeneutics, as he expounds later on, has to consist in a diligent, i.e. differentiated and

1 Cf. L. Fladerer, Antiochus v. Askalon: Hellenist und Humanist (Graz, 1996), pp. 43-8.

2 On the topic in Arabic philosophy as a whole cf. G. Endress, 'La concordance entre Platon et Aristote, l'Aristote arabe et l'émancipation de la philosophie en Islam médiéval', in B. Mojsisch and O. Pluta (eds.), Historia philosophiae medii aevi. Studien zur Geschichte der Philosophie des Mittelalters (Amsterdam/Philadelphia, 1991), pp. 237-57 and C. D'Ancona, "The topic of 'Harmony between Plato and Aristotle': Some examples in early Arabic philosophy', in A. Speer and L. Wegener (eds.), Wissen über Grenzen. Arabisches Wissen und lateinisches Mittelalter (Berlin/New York, 2006), pp. 379-405.

3 The best edition is the most recent one: al-Fārābì, L'armonia delle opinioni dei due sapienti, il divino Platone e Aristotele, ed. C. Martini Bonadeo (Pisa, 2008). As this edition is far less widespread yet than the earlier one by D. Mallet and F. Najjar (L'harmonie entre les opinions de Platon et d'Aristote [Damascus, 1999]) the text will be quoted here in referring to Najjar's paragraph- and Bonadeo's page-numbering. As to the issue of the authenticity of the text, its most recent editor can, however, not be said to have resolved all the considerable doubts raised by J. Lameer, Al-Fārābi and Aristotelian Syllogistics: Greek Theory and Islamic Practice (Leiden 1994), pp. 30-9; M. Rashed, "Al-Fārābī's lost treatise On Changing Beings and the possibility of demonstration of the eternity of the world", Arabic Sciences and Philosophy, 18 (2008): 19-58; "On the authorship of the treatise On the harmonization of the opinions of the two sages attributed to al-Fārābl", Arabic Sciences and Philosophy, 19 (2009): 43-82 (cf. esp. his reply to Endress and Bonadeo ibid., pp. 75-82) and D. Janos, "Al-Fārābī, creation ex nihilo, and the cosmological doctrine of jam and jawābāt", Journal of the American Oriental Society, 129 (2009): 1-17.

4 Harmony $\S 1$ (36,5-37,2 B.). 
irenical, treatment of the most important authorities in a scientific field: One educated and qualified mind outweighs any kind of uncritical and uneducated mass, no matter how numerous it may be. If, however, two educated, critical and independent minds agree on a certain subject-matter, their can be no better proof for the truth of their opinion. ${ }^{5}$ The most valuable criterion of truth in philosophical matters is thus, for our author, the consensus of the most outstanding philosophical minds, Plato and Aristotle, which at the same time validates the philosophical quest for knowledge as being not only possible, but also fruitful and important.

Yet, even if this quest could actually yield valid and productive results in every scientific field, what if in one or more of the two authorities yielded a conclusion contrary to the religious law of Islam? This possiblity is never touched by our author explicitly, ${ }^{6}$ although it clearly lies behind his entire attempt to free the two philosophers from any suspicion of this kind. As he claims right in the beginning, the starting-point of the entire discussion he is about to enter was the question of creation or eternity of the world, ${ }^{7}$ a question which - at least according to the Neoplatonic philosophers of late antiquity - was answered by both Plato and Aristotle unanimously in the latter sense. In many educated Muslims this will of course have created the impression that philosophical science was entirely irreconcilable with revelation and thus had to be proven self-contradictory - a tradition which was to culminate in Ghazzālī's Tahāfut. In contrast, our author tries to present Plato and Aristotle as having originated (natural) philosophical science just in their unanimous discovery of the creatio ex nihilo, which for the first time lifted human speculation about the beginning of the world above the level of lore and myths, as those still believed by the Jews and Zoroastrians, and provided a scientific basis for it. ${ }^{8}$

Judged on the basis of modern historical research, our author thus arrives at an outright reversal of the actual historical development: An idea which had its roots in early Judaism ${ }^{9}$ (and was developed into a doctrine by Christian apologists ${ }^{10}$ ) is denied to the Jews and transferred to Plato and Aristotle, both of which explicitly denied it

${ }^{5}$ Harmony $\S 4(39,1-40,3$ B.).

${ }^{6}$ Cf. however his warnings regarding the difficulty and unavoidable ambiguity of religious language (Harmony $\S \S 66 \mathrm{f} ; 69,15-70,16$ B.).

7 Harmony $\$ 1$ (36,5-8 B.): "As most people of our time are stimulated to argue about the creation of the world and its uncreatedness and affirm that there is a difference between the two preceding and outstanding sages regarding their affirmation of a first beginning...".

8 Harmony $\S 58(66,1-67,3 \mathrm{~B}$.).

9 The classical reference is 2 Maccabees 7:28: "I want you, child, to look at heaven and earth and then, seeing all this, know that God created it out of nothing".

10 Cf. G. May, Schöpfung aus dem Nichts. Die Entstehung der Lehre von der creatio ex nihilo (Berlin, 1978). 
in affirming the eternity of matter. The attitude ascribed here to the uneducated masses, that they are unable to imagine a thing originating from nothing and perishing into nothing, ${ }^{11}$ is even explicitly argued for by Aristotle in De generatione et corruptione I 3 $317 \mathrm{~b}^{12}$ and was not to be combatted philosophically before John Philoponus, ${ }^{13}$ who was in turn attacked by al-Fārābī for criticizing Aristotle's theory of sublunar elements and the (eternal) substance of heaven. ${ }^{14}$

The purpose of the following examination is to show that this stunning reversal is not merely due to a completely misguided desire for harmony between theological and philosophical doctrines or even to mere mistranslations, interpretative misunderstandings and deceptions like accepting the De mundo or even the Theology of Aristotle as authentical works, but has important roots in the Neoplatonic interpretation of both Plato and Aristotle. If one wants to read the creatio ex nihilo into Plato and Aristotle, there are two contrary assertions of the two philosophers which have to be reinterpreted before all others: Plato's affirmation of a preexistent chaos or chaotically moved matter in the Timaeus and Aristotle's wholesale denial of divine creative activity. Only because the Neoplatonists had already dealt with both of them and interpreted both philosophers as unanimously presenting a doctrine of eternal creation, their Muslim disciple got the chance to 'invert' this harmony and understand both (in the case of Aristotle obviously with a lot more interpretative violence) as in fact aiming at a creatio ex nihilo. Our examination thus has to proceed in three steps, the first two of which will have to document the Neoplatonists' dealing with the two aforesaid problems. In a third, final step we will have to analyse the relevant passage in our treatise as to its debt to the relevant Greek sources. Finally, we will have a look at al-Fārābī's doubtlessly authentic presentation of Plato's and Aristotle's philosophy and give some thoughts to the question, how this might be related to what we read in the Harmony.

11 Harmony $\S 61(68,5-10)$.

12 The possibility that all things might be made "from nothing" is also rejected as evident non-sense in the most prominent passage of the Metaphysics (XII,7 1072a20; XII,10 1075b14f).

${ }^{13}$ Cf. De aeternitate mundi contra Proclum IX,8-17 (ed. H. Rabe [Leipzig, 1899; repr. Hildesheim, 1984], pp. 338-80). For the influence of this treatise, which was translated into Arabic in its entirety, on the Arabic discussion of the creation problem cf. H.A. Davidson, "John Philoponus as a source of medieval Islamic and Jewish proofs of creation", Journal of the American Oriental Society, 89 (1969): 357-91.

14 Cf. M. Mahdi, "AlFarabi against Philoponus", Journal of Near Eastern Studies, 26 (1967): 233-60. 


\section{TIMAEUS WITHOUT CHAOS}

Our author's claim that Plato and Aristotle overcame the ancient creation mythology predominant in other philosophical schools and religions by their scientific account of creatio ex nihilo is all the more astonishing, if one takes a look at the Timaeus and finds Plato expounding a creation myth in many respects strongly reminiscent of the one in book of Genesis or similar ancient oriental texts: In the beginning of all three parts of his exposition, Plato's creator god, the Demiurge (artisan), first encounters a preexistent chaos and then brings order and symmetry into it according to the principles of reason in fashioning it after the intelligible paradigm (Tim 29e-30a; $52 \mathrm{e}-53 \mathrm{c} ; 69 \mathrm{a}-\mathrm{c})$. Christian readers of the Timaeus had thus always been criticizing Plato for a deficient knowledge of the creator, whom he prudently acknowledges, yet denies his omnipotence by making him depend on preexistent matter. ${ }^{15}$ For the Arabs, however, the Timaeus was both accessible in Ibn al-Bitrīq's translation (now lost) ${ }^{16}$ and in Galen's paraphrase, in which the mythological elements of presentation have almost completely vanished. ${ }^{17}$ Instead, Galen presents an interpretation, which for a Muslim reader must have been at least as offensive as the Neoplatonist one, namely the reading initiated most probably by Plutarch of Chaironeia: According to this reading, the precosmic chaotic movement is caused by the ungenerated evil world-soul hypothetically introduced in Plato's Laws (X 896e-897b), which the Demiurge afterwards transforms into the generated, good and rational soul of our cosmos (Tim 34b-36d). ${ }^{18}$ This odd interpretation, which was fiercely rejected by later Platonism, is stated in Galen's paraphrase not only pretty unequivocally, but also in a way which makes it very difficult for the reader to distinguish between Plato's text and Galen's interpretation. ${ }^{19}$ Thus, our author could never have arrived at his picture of Plato in relying on the primary sources available to him, ${ }^{20}$ but rather takes

15 Cf. e.g. Athanasius, De incarnatione II,3. On the Christian attempts of reading the creatio ex nihilo into Plato cf. my Platon und Aristoteles in der Kosmologie des Proklos. Ein Kommentar zu den 18 Argumenten für die Ewigkeit der Welt bei Johannes Philoponos (Tübingen, 2009) (STAC 54), pp. 56-8.

16 Cf. G. Endress, "Die wissenschaftliche Literatur", in W. Fischer (ed.), Grundriss der arabischen Philologie, vol. III: Supplement (Wiesbaden, 1992), pp. 2-61, on p. 29.

17 Cf. Galeni compendium Timaei Platonis, ed. P. Kraus and R. Walzer (London, 1951) (Arabic text and Latin translation). The passages corresponding to the aforementioned chaosdescriptions would be Compendium IIde, VIIIb-IXd (which in its present state suffers of several crucial lacunae) and XVIIa.

18 On this tradition of Timaeus-interpretation cf. M. Baltes, Die Weltentstehung des platonischen Timaios nach den antiken Interpreten, vol. I (Leiden, 1976), pp. 38-69 and his Der Platonismus in der Antike, vol. 5 (Stuttgart, 1998), Bst. $136 \mathrm{f}$.

19 Cf. esp. Compendium IVab.

20 The reference to the teleogical expositions in the books on anatomy and "on the usefulness of body-parts" (De usu partium) (Harmony § 59) clearly has in mind works of Galen, and the 
the Neoplatonic interpretation of the Timaeus as in many respects unquestioned starting-point. In this interpretation, neither the precosmic chaos nor the diverse fashioning-acts of the Demiurge are to be taken litterally, as this would entail the (metaphysically desastrous) priority of the chaos to the cosmos. Hence, already Proclus dismisses Plutarch and his followers pretty quickly in stating:

The school of Porphyry and Jamblichus rebuke this opinion, because it locates chaos before order, deficiency before perfection, mindlessness before mind also in the universal dimension and thus commits blasphemy not only against the (divine) cosmos, but also against the Demiurge himself, as it completely abrogates either his good-shaped will or his creative power. For, if both come together, the cosmos has to be created by him eternally. ${ }^{21}$

That unnatural chaotic movement cannot have priority before the naturally ordered one, had already been pointed out by Aristotle, mainly in De caelo III,2. If, as Plato says, the creation of the cosmos is preceeded by an infinite time of chaotic material movement, there is no way of maintaining the natural character of the present order: As Plato admits the existence of elements before the cosmos (Tim $53 \mathrm{ab} ; 69 \mathrm{~b}$ ), their movement has to be either natural or unnatural. However, if it were natural, the masses of elements would make up the same order as they do now, and there would be no need of a demiurgic act of organization (De caelo III,2; 300b17-25). Yet, if it were unnatural or forced, this claim would be self-contradictory, as it would entail an eternal precosmic unnatural state without the opposite natural one, which the Demiurge would have always been about to establish (301a4-11). In short: Any kind of unnatural state always presupposes the natural order, as it always consists in a deviation from the established natural state. For Aristotle, this entails not only that nothing unnatural can be eternal (as the precosmic chaotic movement would in some sense be, if it were ungenerated), ${ }^{22}$ but also that the natural order has to be eternal, if 'natural' is to be determined as the state a thing has always or at least most of the time (Physics II,8 198a35f).

This metaphysics of nature was recognized by the Neoplatonists as basically Platonic, which made it difficult for them to understand, why Aristotle did not grant these obvious insights to his master and

reports on the Timaeus elsewhere (e.g. Harmony $\S 71)$ do not witness to a closer acquaintance with the dialogue.

21 In Platonis Timaeum commentaria, ed. E. Diehl, vol. 1 (Leipzig, 1903), 382,12-20 (French translation in Proclus, Commentaire sur le Timée, trans. A.-J. Festugière, 5 vols. [Paris 1966-68]). The gist of this argument appears - in an ethical context - already in Plotinus, Ennead III 2, 4,26-36.

22 Cf. De caelo II,3 286a17-19: "Nothing unnatural is eternal. For the unnnatural is later than the natural, and the natural is a deviation from the natural in any kind of process." 
accordingly interpret the Timaeus metaphorically, not as litterally and superficially as he did. Yet, the metaphorical interpretation of the Timaeus had been known already to Aristotle himself and had been rejected by him on the following grounds:

If the generation in the world presented by Plato had to be understood metaphorically, in the sense a geometrician "generates" an eternal figure by constructing it in front of the pupils in order to demonstrate step by step its eternal structure, there would be no room for steps of contradictory content. The picture had to be the same, no matter if painted step by step or projected simulaneously as a whole. As Plato's description, however, does contain such steps of contradictory content, namely the descriptions of chaos and order, it has to aim at a real process temporally mediating between the two extremes which as simultaneous would be mutually exclusive. ${ }^{23}$ In fact, this argument points to a crucial problem of the metaphorical interpretation ${ }^{24}$ : If the mythical narration of the creation-process is in fact nothing but a description of an eternal structure, does every narrative element equally represent an aspect of this structure or are some to be considered mere ornaments or illustrations? Jamblichus was obviously urging the first possibility, when he rejected a merely pedagogical interpretation of the processual structure of the dialogue, as this might make also of the Demiurge himself a replaceable means of demonstration. ${ }^{25}$ Regarding the descriptions of chaos, however, the later Neoplatonists still seem to have pursued a twofold strategy: In some contexts, Proclus clearly makes of it a remaining aspect of the cosmic structure in identifying it with the subterranean sediments of the four elements he also finds described in the closing-myth of Plato's Phaedo (109c; 111c-113c). ${ }^{26}$ This explanation, however, does not cover the descriptions in their entirety and in all their aspects: Especially the phrase Tim 53b2f, where Plato remarks that in the precosmic state everything was "exactly as it should be like, when God is absent from something", brought him to believe the chaos-descriptions to be basically thought-experiments, abstractions illustrating the present order ex negativo. In the eighteenth argument refuted by Philoponus he

${ }^{23}$ De caelo I, 10 (279a33-280a11) = Baltes, Platonismus V, Bst. 136.0b (German translation and commentary).

24 The fact that Timaeus-description cannot be interpreted as a temporal process, is also

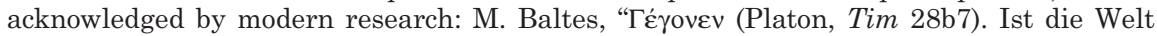
real entstanden oder nicht?", in K.A. Algra (ed.), Polyhistor. Studies in the History and Historiography of Ancient Philosophy: Presented to Jaap Mansfeld on his Sixtieth Birthday (Leiden, 1996), pp. 76-96.

25 Cf. Baltes, Weltentstehung I, 170f.

26 Cf. my Platon und Aristoteles in der Kosmologie des Proklos, pp. 404-7. 
describes it as a Plato's "divine contrivance" to describe a chaotic world per absurdum as absence of God:

And this I would truly call a divine contrivance of Plato's wisdom, which proves the ungeneratedness of the cosmos together with its imperishability from God's eternal effectivity, to identify the reason of order and chaos in the cosmos as God's presence and absence. For if this alone can be the reason for order and chaos on the side of the cosmos, but has no correspondence in reality, as God can impossibly behave differently at different times, it is also impossible to see order and chaos in the cosmos. If God always behaves identically, he is not persent to the cosmos at one point and absent at another. If he is not present at one point and absent at another, the cosmos is also not in order at one point and in chaos at another, as only the presence of God caused the order for the cosmos and only his absence chaos. ${ }^{27}$

This means, however, that for Proclus Plato's descriptions of precosmic chaos in the end rather expound the impossiblity of such a chaos, as it could only come true in the impossible case of the Demiurge himself being absent from his creation. Thus, Plato's chaos has become as "inexistent" 28 as it needs to be to prepare for reading the creatio ex nihilo into the great Greek philosopher.

Although this text is not explicitly referred to in the Harmony it was very widespread and popular in contemporary philosophical circles, ${ }^{29}$ as can be shown especially from al-'Ámirī's Book on the Afterlife. In a passage thoroughly analyzed by C. D'Ancona, ${ }^{30}$ al-'Ámirī expounds a solution of the classical problem of Timaeus-exegesis, i.e. how the cosmos or, more specifically, the world-sould, can be called both generated and ungenerated by Plato, which basically goes back to the one proposed by Porphyry: As (1) "generated" has to be understood in the sense of "composed from matter and form", (2) form has to be simultaneous with matter and (3) both were created by the demiurge, the latter has to create the world all in all from nothing within no time. This argument perfectly elucidates how the Neoplatonic tradition was dealt with in Arabic anti-eternalist philosophical circles: Proposition (1)-(3) are all thoroughly Neoplatonic, (1) being probably borrowed from Philoponus' report on Porphyry in his refutation of Proclus' sixth argument, ${ }^{31}$ (2) and (3) stemming from argument eleven and twelve and three and fourteen respectively. Yet, as soon as the "creation" from proposition (3) is no longer understood in

27 Philoponus, De aeternitate XVIII (ed. Rabe, 607,6-20). Cf. my commentary on the text in Platon und Aristoteles in der Kosmologie des Proklos, pp. 457-64.

28 In the text quoted above, Proclus calls God's absence (and following presence) whithout "correspondence in reality" or "inexistent" (anhypostatos; 607,13) and thus of course also the precosmic chaos caused by it.

29 Cf. e.g. Davidson, "John Philoponus".

30 "The topic of 'Harmony", pp. 391-8.

31 De aeternitate mundi VI,8 (ed. Rabe, 144,16-149,26). 
emanationist, but in theistic terms, the conclusion drawn from that is exactly the opposite one.

\section{THE UNMOVED MOVER AS A CREATOR}

In the preserved corpus, Aristotle never explicitly attacks the concept of a creator-God in general or the Platonic demiurge in particular, except maybe in one famous passage from the Metaphysics, where he criticisizes Plato's doctrine of ideas:

To claim that the ideas are paradigms and that all other things participate in them, is to speak nonsense and to talk in poetical metaphors. For what is it that creates looking up at the ideas?! (I,9; 991a20-22)

As the latter phrase is strongly reminiscent of Plato's description of the Demiurge (cf. Tim 28a-29a; 39e), Aristotle might interpret the Demiurge here as mere poetical metaphor for the creative power of the paradigm or the ideas, an interpretation also taken up by modern research. ${ }^{32}$ However Aristotle may have understood Plato's creator, he did attack the general concept of a creator-god in his lost treatise De philosophia, ${ }^{33}$ which also contained very important physical arguments for the eternity of the world. ${ }^{34}$ This explains, why in the relevant passages of the preserved lectures (esp. Physics VIII, De caelo I,10-II,1, Metaphysics XII,6-10) he is so short on many important aspects of the topic (Physics and Metaphysics limit themselves to the eternity of time and movement, the De caelo-passage primarily wants to prove the impossibility of a generated, yet unperishable world, as posited - in Aristotle's eyes - by Plato), as he presupposes a familiarity with his arguments in the aforesaid treatise. Of course, this also explains - at least partly - later attempts to read the idea of creation into his texts, be it temporal as in the case of our author, or be it eternal as in the case of the Neoplatonists.

That those were - despite this crucial difference - an important source for our author's (mis-)reading, is - contrary to the case of eleminating precosmic chaos from Plato - made explicit by the Muslim philosopher: Next to the Arabic Theology of Aristotle he refers to a treatise of Ammonius, son of Hermeias, head of the Alexandrian school in the first decades of the sixth century. Ammonius, he says, wrote a monograph on the sayings of the two sages concerning the affirmation of the creator, which is yet too well known to draw upon

32 Cf. e.g. A.J. Festugière, La révélation d’Hermès Trismégiste, vol. 2: Le Dieu cosmique (Paris, 1949), pp. 145-9.

33 Cf. B. Effe, Studien zur Kosmologie und Theologie der Aristotelischen Schrift "Über die Philosophie”, Zetemata 50 (München, 1970), pp. 23-31 (mainly on the famous frg. 22 Rose [= Cicero, Lucullus 119] and some parallels).

34 Cf. my Platon und Aristoteles in der Kosmologie des Proklos, pp. 262-73. 
it any further. ${ }^{35}$ Unfortunately, to the knowledge of our times this monograph is lost and we can get only a vague idea of its contents from a few references in the Aristotelian commentaries of Simplicius, one of Ammonius' disciples. ${ }^{36}$ In the most extensive report in the commentary on Physics VIII,10, Simplicius presents the following of Ammonius' arguments: First of all, Ammonius seems to have shown that also the Platonic demiurge fulfills the most important Aristotelian criteria for the first cosmological principle: He is both to be regarded as a final cause, as he does everything for the sake of the good thus structuring the universe teleologically (cf. esp. Tim $29 \mathrm{e}-30 \mathrm{~b}$ ), and remains immobile, as he delivers the creation of perishable things to the young gods while "abiding in his own proper and wonted state" himself (Tim 41a-42e). Thus, just as in Aristotle, the unmoved mover or Demiurge is to be regarded as immediate cause only regarding the translunar, imperishable realm while causing the sublunar, perishable realm through the mediation of the stars. ${ }^{37}$

The following proof, that Aristotle conceived his final cause as an efficient cause as well, is of course more complicated and at first sight seems to be rather a collection of questionable dicta probantia: Aristotle calls the efficient cause "principle of movement" (Physics II,3; 194b29-32), he has God or nature "do nothing in vain" (De caelo I,4; 271a33), ${ }^{38}$ he calls being and life of all things dependent on the divine Aeon (De caelo I,9; 279a27-30), he reduces everything to the two causes of moving-principle and matter (De generatione et corruptione I,3 318a1-5) and thus has to assign the (efficient) creation of movement (according to the respective forms) to the former, and finally, just as Plato in the Phaedo (97b-98b), he praises Anaxagoras for having introduced the intellect as the principle of the entire natural order and movement (Metaphysics I,3; 984b15-22). ${ }^{39}$

In all those passages, however, Aristotle speaks of the intellect or unmoved mover as imparting order and movement on the universe, ${ }^{40}$ not as creating its substance. Hence, Ammonius' argument would be rather weak, if he actually intended to conceal this difference just

35 Harmony $\S 58$ (66,1-67,3 B.).

36 Cf. In Aristotelis de caelo commentaria, ed. J.L. Heiberg (Berlin, 1894) (CAG VII), 271,13-21 and In Aristotelis Physicorum libros VIII commentaria, ed. H. Diels, vol. 2 (Berlin, 1895) (CAG X), 1360,24-1363,24. On the background cf. the comments of K. Verrycken, "The metaphysics of Ammonius son of Hermeias", in R. Sorabji (ed.), Aristotle Transformed. The Ancient Commentators and their Influence (Ithaca, 1990), pp. 199-231, on pp. 216-25.

37 CAG X, 1360,31-1361,11.

38 Aristotle's famous teleological principle: Politics I,1,9 1253a9; De caelo II,11 291b13f; De generatione animalium 741b4f; De incessu animalium 711a18; De partibus animalium $658 \mathrm{a} 8 \mathrm{f}$ and $695 \mathrm{~b} 19 ;$ De respiratione $486 \mathrm{a} 12 \mathrm{f}$.

39 CAG X, 1361,11-1362,10.

40 De caelo I,9 cannot really count as an exception, as this passage merely explains the meaning of the term "Aeon" as "lifetime", and the dependence of someone's being on his lifetime can of course not really be called an efficient-causal one. 
by pointing to the terminology of the Physics-passage adduced in the first place, where the efficient cause is called principle of movement. The next paragraph of Simplicius' report seems, however, to dwell exactly on this point: Against Alexander's of Aphrodisias and other commentators' emphasis on the merely teleological causality of the unmoved mover, Ammonius quoted, according to Simplicius, Alexander's commentary on De generatione I,3 318a1-5, where the unmoved mover was called "efficient cause of the ungenerated movement of the divine (heavenly) body" - for a Peripatetic philosopher a very important concession, as this allows for a (temporally) ungenerated thing to nevertheless have an efficient cause. Afterwards, he discusses Physics II,6 198a2-13, where Aristotle argues that the universe cannot have been created by chance, as chance is only the cause of something per accidens, whereas intellect and nature are causes per se. This argumentation, as Ammonius (or Simplicius) admits, is merely hypothetical. However, just as most of the other passages mentioned above, it becomes relevant, if one takes into account one important point. And this important point, finally, is the metaphysical argument the entire Neoplatonic reading of Aristotle depends upon:

Yet, one has to take into account that everything which is moved by something else also has to receive its existence from elsewhere, as substance is more than movement. If, according to Aristotle, the power of every limited body is itself limited, the power to move just like the power to sustain its own substance, it is necessary that, just as it gets eternal movement from the unmoved cause, it receives also its eternal corporeal substance from the incorporeal cause. ${ }^{41}$

To conclude his report, Simplicius makes a remark on why Aristotle was so reluctant to call his first principle efficent cause: He feared that efficient causality might be too closely associated with the production of temporal individuals and thus endanger the belief in the eternity of heaven and universe. Thus, he distinghuishes between genesis (generation, becoming) and kinessis (movement, processuality) only for pedagogical reasons, although in fact both terms mean practically one and the same thing. ${ }^{42}$

Hence, according to the Neoplatonists, the movement of a corporeal thing is not only with regard to its causation inseparable from its essence, but its movement and essence are practically identical, as a corporeal thing "has its being in its becoming". This claim not only reflects the wide semantic range of the Greek terms genesis and

${ }^{41} C A G \mathrm{X}, 1363,2-8$. On the importance of the principle that no limited body can have unlimited power (proved by Aristotle in the beginning of Physics VIII,10) cf. my Platon und Aristoteles in der Kosmologie des Proklos, pp. 203-28.

${ }^{42}$ CAG X, 1363,12-24. 
kinessis signifying almost any kind of processuality, but also an important piece of Platonic metaphysics which Aristotle had not been able to get rid of completely. In the Platonic idea, efficient, formal or paradigmatic and final causality necessarily coincide, as the idea in its absolute determination and identity creates its images just by being, what it is, as the undetermined matter strives for and tries to imitate being and identity, thus receiving a form wherever it proves to be fit. Thus, the reign of ideas, identity or being has to be clearly distinguished from the reign of extended, self-alienated material beings or becoming (cf. Tim 27d-28a). Material 'being' never really is, i.e. fully determined and always self-identical essence, but has its being in becoming or trying to become true being always emulating the idea and striving for it. What Aristotle tried to do, was to formalize this strive in that material beings for him are determinated in essence by their immanent formal cause (not by a transcendent idea), but still strive for the actualization of this essence in exercizing the processes natural to them, thus emulating the perfect actuality of the unmoved mover. However, if those essences only become actual in their natural processes triggered by the emulation of the unmoved mover, the Neoplatonists understandably saw a twofold problem to be resolved by a single Platonic solution: Firstly, if every natural essence necessarily realizes itself in different processes, is the distinction between essence and process really tenable and would not the one triggering the process also have to be made responsible for the essence? Secondly, if the different natural essences do not depend in any way on the unmoved mover, why do they strive for his actuality? Does not any strive presuppose a fundamental kinship, so that potentiality only strives for actuality, if it had not only its aim, but also its origin in the latter? Supposed, however, the movement Aristotle's unmoved mover and his diverse sphere-movers (cf. Metaphysics XII,8) trigger, is not strictly to be distinguished from the essence of material beings, but rather constitutes it, both problems would immediately be solved, as their causality would then be very similar, if not identical with that of a Platonic idea. ${ }^{43}$

Thus, the Neoplatonists had at least shown with pretty convincing arguments that Aristotle had not been able to get rid of the metaphysical concept of creation completely. At any rate, for a late antique reader of Aristotle they made it very questionable, if not almost impossible that Aristotle's first principle was intended to be the final cause of the universe exclusively. However, if this creation should be understood not in the Platonic (eternally-paradigmatic),

43 How those ideas were developed at first to defend Plato against Aristotle's criticisms and then to harmonize the two philosophers completely, I tried to show in my Platon und Aristoteles in der Kosmologie des Proklos, esp. pp. 27-30 and 214-19. 
but in a muslim, theistic way, their arguments were anything but simple to adapt, which will have been the real reason, why our author for elaborating his creationist picture of Aristotle rather appealed to the Arabic Theology than to the alledgedly so well-known treatise of Ammonius.

\section{THE CREATIONIST SYNTHESIS PROPOSED IN THE HARMONY}

Our author's most important source for his harmonization of Plato and Aristotle with respect to the problems of creation, ideas and the relationship between intellect, nature and soul is obviously the so-called Theology of Aristotle, the inauthenticity of which he actually considers, yet rejects on the ground's of the book's widely accepted reputation. ${ }^{44}$ The utilization of this and other related documents is, however, beyond the scope of the present study. ${ }^{45}$ What has to be examined here, is our author's reading of the authentic Aristotelian text and its possible Neoplatonic background. That this background is of major importance for the interpretation proposed in our text, might be doubted considering the fact that he is aiming at the conclusion exactly opposite to the Neoplatonist one: The world does no longer have to be eternal according to both Plato and Aristotle, but has to be created from pure nothingness. Let us take a closer look at the relevant paragraph of the treatise $(\$ \S 53-76)$ in order to judge, whether this supposition is actually justified. This paragraph can be divided into three subsections: The first one ( $\S \S 54-57)$ deals with several Aristotelian texts on ungeneratedness and 'creation' of the world, tries to show, how they can be understood as not stating the eternity of the world and finally culminates in the aforesaid reference to Ammonius' treatise on the creator-God in Aristotle.

The second one ( $\$ 58-62)$ discusses the relationship between philosophical proof and religious belief, the harmony of which has to be shown before introducing the most important issue in harmonizing Plato and Aristotle: the theologically suspicious doctrine of ideas and the intelligible world ( $\S 63-76)$.

As for the present study, I will restrict myself basically to a detailed analysis of the Neoplatonic background of the first part, as it provides more than enough material to illustrate the way in which our author depends on the Neoplatonists. In this first part, we can distinguish a negative ( $\S 54 \mathrm{f})$ and a positive section ( $§ 57)$, the first one dealing basically with two texts allegedly arguing for the eternity of the world (Topics I,11; De caelo I,10-II,1) and the second one referring

44 Harmony $\S 66$ (70,5f B.).

45 For "creation" in the theology of Aristotle cf. P. Adamson, The Arabic Plotinus. A Philosophical Study of the Theology of Aristotle (London, 2002), pp. 137-55. 
the reader to the Aristotelian Physics and Metaphysics (combined with the Theology of Aristotle) which are claimed to witness clearly to his belief in a creator.

At first sight, the negative part seems to be more than disappointing, as its treatment of the relevant Aristotelian texts is not only very selective ${ }^{46}$ but apparently relies on pretty weak arguments, especially at the outset: Our author claims that readers of Aristotle's text were misled into ascribing to him the denial of a creator by a passage from the Topics (I,11; 104b1-17), where he presents the problem, whether the world is eternal or not, as a dialectical one, concerning which wise men bring forth syllogisms for both alternatives. Obviously, the only possible misunderstanding this passage might have caused in Aristotle's readers would be that he regards the problem in question as theoretically unsolvable, not that he solved it in favour of the world's eternity. Thus, in my opinion, this passage is only adduced as an example for the hermeneutical method he wants to have applied also to those Aristotelian texts really stating the eternity of the world: He emphasizes that the purpose of the Topics is merely logical and that the eternity-problem comes in only as an example for the discussions of his time. ${ }^{47}$ As will finally become clear in the conclusion, when we will turn to al-Fārābì's systematic exposition of Aristotle's philosophy, the emphasis on the systematic angle to be presupposed in a certain text of the Aristotelian corpus is a sign for a certain kind of hermeneutical strategy developped exactly within the attempt of harmonizing the two classical philosophical authorities. Yet, as the Harmony works rather piecemeal advancing different arguments against the eternalist reading of different Aristotelian texts, those strategies are not as evident as in al-Fārābī's doubtlessly authentic treatment of the matter.

As a second text, which will have misled Aristotle's readers, the author refers to the De caelo et mundo, which clearly states the ungeneratedness of the cosmos. ${ }^{48}$ In full accord with the Neoplatonists, our author takes this as the denial of a beginning in time (arche chronikē, bad'un zamāniyyun), as it denies the possiblity that the world could have been generated in the course of a temporal process. Yet, against the Neoplatonists, he argues that, if time is for Aristotle nothing but an attribute of heavenly movement (cf. esp. Physics

46 The - next to the De caelo-passage - most important texts from the Physics (esp. book VIII) and the Metaphysics (esp. book XII) are referred to only in the positive section, whereas many other passages form De generatione and corruptione or the Meteorology are not mentioned at all (on those cf. F. Solmsen, Aristotle's System of the Physical World. A Comparison with his Predecessors [Ithaca, 1960], pp. 420-39).

47 Harmony $\S 54$ (63,1-15 B.). For al-Fārābī's treatment of this passage cf. Rashed, "Al-Fārābī's lost treatise On Changing Beings", pp. 25-9.

48 Cf. esp. De caelo I,10-II,1 (cf. Ps-Aristotle, De mundo 4; 396a30-32). 
IV,11), ${ }^{49}$ there cannot be time before the heavenly movement of our cosmos actually existed, i.e. the heavens themselves cannot have been constructed in time. This simultaneity of time and heaven was, however, explicitly stated already by Plato (Tim 38b), who was harshly criticized by his pupil Aristotle exactly for this claim: If Plato, according to Aristotle, wants the heavens both to be generated by the Demiurge and to come into existence simultaneously with time, he involves himself into the absurdity of postulating a generated, non-eternal time, which would allow for a period (of time) before and after time (Physics VIII,1; 251a8-b10). Yet, as the Neoplatonists' example shows, ${ }^{50}$ those premises could also yield the exactly opposite conclusion: As Plato clearly emphasizes the simultaneity of time and heaven, and time obviously has to be conceived of as eternal, he cannot have intended his generation-process as a temporal (or punctual act), but only as an eternal one. In contrast, for our author, neither Plato nor Aristotle can have regarded time as eternal, as especially Aristotle makes it depend upon the movement of heaven. Although this reversal of the argument most probably goes back to Christian predecessors, especially John Philoponus, ${ }^{51}$ its Platonic background is still obvious: In Tim 38c-39d the Platonists read that the stars were created, not only in order to measure time (39bc), but in order to generate it (38c). Thus, if time is eternal, yet created by the stars, those have to be eternal a fortiori..$^{52}$

Even with all the exegetical traditions in their back those arguments remain pretty weak. This is probably why our author in his transition to the positive section hints at the necessity of taking a different angle on Aristotle's relevant expositions in the physical writings: First of all, we have to consider his sayings about rubübiyya, the Arabic translation for the Greek 'theology',53 i.e. mainly the clear statement of the creatio ex nihilo in the Theology of Aristotle, if we want to interpet the physical writings correctly. Afterwards, he presents a concise cento of references to several

49 Harmony $\S 55$ (63,18 B.: "in this book [i.e. De caelo] and others of his physical and metaphysical books") refers more exactly to De caelo I,9 (279a14f), Physics IV,11 (219b1f a.e.), De generatione II,10 337a24f, and possibly to Metaphysics XII,5 (1071b9f).

50 Cf. e.g. Proclus' fifth argument in Philoponus and my extensive commentary in Platon und Aristoteles in der Kosmologie des Proklos, pp. 160-80.

51 Cf. De aeternitate mundi V,3 (ed. Rabe, 109,27-111,18) (for an English translation cf. John Philoponus, Against Proclus on the Eternity of the World 1-5, trans. by J.M. Share [London, 2004]); Contra Aristotelem frg. 121 Wildberg (Against Aristotle: On the Eternity of the World, trans. by C. Wildberg [London / Ithaca 1987]).

52 Cf. the anti-stoic argument in Philo of Alexandria, De aeternitate mundi, ed. R. Arnaldez, J. Pouilloux (Paris, 1969), §§ 52f.

53 Cf. e.g. the titles of the Proclus-translation in the manuscripts, which all explain uthūlüjiy $\bar{a}$ as rubūbiyya (G. Endress, Proclus Arabus. Zwanzig Abschnitte aus der Institutio theologica in arabischer Übersetzung [Wiesbaden, 1973], p. 3). 
Aristotelian and Platonic texts which has to be quoted in full in order to evaluate its possible implications:

And Aristotle makes clear in the lectures on Physics that the generation of the universe was not possible by chance or coincidence, a claim he also makes concerning the world as a whole in the book on heaven and world in referring to the admirable order which is to be found among the different parts of the world as his proof for that. There, he also explains the issue of causes, how many there are, and lists the efficient causes. As well, he explains there the issue of the generator and mover, that he is ungenerated and unmoved, just as Plato in his book known as Timaeus makes clear that every generated thing is only brought into existence by a cause generating it necessarily and that the generated thing is not the cause of his own generation. ${ }^{54}$

At first sight, this passage seems very general and unprecise in its argumentation. If we suppose, however, a knowledge of Ammonius' treatise in our author and his readers (cf. the table at the end of the article), the case he presents becomes much more complex: Just like Ammonius, he refers to Aristotle's treatment of chance (tychē) and coincidence (automaton) as possible physical principles in Physics II,4-6, ${ }^{55}$ just like Ammonius, he refers to the basics of the four-causes theory in Physics II,3, and again just like Ammonius, he refers to the unmoved principle of movement from Physics VIII. As we have seen in analyzing the Greek testimonies on Ammonius, all those passages can only serve as evidence for a creator in Aristotle, if one accepts the Neoplatonic parallelization or in a certain respect even identification of movement and generation. Thus, the outright identification of the mover and the generator can only be understood from an acquaintance with Ammonius' treatise. Moreover, the Timaeus-quotation he adduces (28a) points exactly into the same direction: Immediately before his report on Ammonius' treatise Simplicius parallelizes the line of argument in Physics VIII,10 with the one in Tim 27d-28c in a manner which might prove very elucidating for our author's short remarks: Just as Aristotle makes clear the insufficiency of the corporeal world for sustaining an eternal movement ("no unlimited power in a limited body"56) and thus posits an eternal incorporeal and unmoved principle which has to sustain it, Plato starts with the deficiency of the world of becoming (27d-28a), which cannot be self-sufficient and is thus with absolute necessity dependent upon an eternal cause:

\footnotetext{
54 Harmony $\S 56(64,7-65,17)$.

55 In $63,11 \mathrm{ff}$ our author adds a reference to the De caelo et mundo which much better fits the Ps-Aristotelian De mundo, where the harmony (and imperishability) of the cosmos as a whole (in contrast to the possibly chaotic and perishable state of its parts) is emphasized in ch. 5 and its origin in divine providence described in the very theistic ch. 6 . In the $D e$ caelo, the cosmic order figures only as a proof for the eternity of the world, not for its dependence on a first cause or creator (cf. esp. III,2 301a4-20 and I,10 280a12-24).

56 Cf. ab. n. 41.
} 
The entire corporeal realm, as it is extended by substance and by this extension of being subject to time and change, Plato ranks as generated and having its being in becoming and because of this dependent on a cause as unable to subsist by itself (authypostaton). 'For everything, he says, it is impossible, to undergo its generation without the cause' [Tim 28a]. [...] Thus, he found the Demiurge of the cosmos, a noeric god, who truly is and always behaves identical as established in the Aeon, in proceeding from the mutable substance of the world up to the the immutable cause. Aristotle as well proceeded from motion and change and the extended and limited corporeal entities up to the unmoved, immutable and unextended cause. For he showed that the movement in reality has to be eternal and thus also the reality moved, as movement inheres in the moved reality. Yet, he also showed that every moved reality is moved by something else and that the primarily moving reality has to be an immobile and immutable cause for the things moved in immediate proximity to eternal motion. That the Platonic becoming (genesis) and the Aristotelian movement (kinessis) both signify change, can easily be learned from Plato's distinction between identical and immutable being and becoming as mutable and from the fact that Aristotle, when he claims that every moved reality is moved by something else, does not talk about the properly moved things only, but also about things coming to be and perishing and in general about changing things. For many times he called the immobile cause immutable, as it does not transcend only the proper movement, but also coming-to-be and perishing. ${ }^{57}$

This passage might help to understand the seemingly superfluous remark inserted into the Timaeus-text that "the generated thing is not the cause of the generation of its own self": This remark might take up a key term from the Neoplatonic argumentation just quoted, namely the term authypostatos, self-subsisting. In this case, the statement about the mover and generator in the Physics and the Timaeus can in fact be regarded as a harshly abbreviated version of the argumentation quoted from Simplicius, which most probably appeared in a similar form also in the relevant treatise of Simplicius' teacher Ammonius. Thus, the only thing our author needed to do in order to bring Physics and Timaeus into creationist harmony, was to suppress the very first step of Aristotle's resp. Simplicius' argument, the eternal nature of (time and) movement.

In contrast, his subsequent treatment of Metaphysics XII is much more complicated, perhaps because he did not have similar Neoplatonic comments on the passage available. ${ }^{58}$ He treats this

57 In Phys., CAG X, 1359,14-38. For the Demiurge as a "noeric god" cf. my Platon und Aristoteles in der Kosmologie des Proklos, pp. 102-12.

58 In his treatise on the scope of the Metaphysics, al-Fārābī complains that there is no all-encompassing commentary on the work available, only an incomplete one of Alexander and one of Themistius on the entire book XII (Alfarabis philosophische Abhandlungen aus Londoner, Leidener und Berliner Handschriften, ed. F. Dieterici, [Leiden, 1890], p. 34). 
book from the Metaphysics as if it succeded the establishment of certain "propositions" (muqaddimāt) Aristotle is said to have established in his theology, namely:

1 "that the one is present in every multitude"

2 "what contains the one in this world, is only one in such and such a respect, and if it is not truly one, but every one is just present in it, the one is different from it, and it is different from the one"

3 "the true one is that which emanates oneness on the rest of reality"

4 "the many is undoubtedly after the one, and the one precedes plurality"

5 "every multitude close to the true one comes before every multitude among those that are far from it and the other way round"59

As already noticed by G. Endress in his pioneering study, ${ }^{60}$ those propositions clearly go back to the Arabic Procliana. The preserved translation of 20 propositions from Proclus' Elements of Theology 61 starts off by translating the first proposition ("every plurality participates in a way in the one") almost verbatim as we read it in the Harmony. ${ }^{62}$ Yet, this is about as far as the verbal correspondence goes. Proceeding with the comparison, one will find only (but as such still pretty clear) correspondence of content: Proposition (2) takes up the Proclean propositions 2 ("all that participates in the one is both one and not one") and 4 ("every unified thing is different from the one itself"), proposition (3) parallels Proclus' third one ("all that becomes one, becomes one by participating in the one") and the fourth proposition is again almost identical with the fifth Proclean one ("every plurality is second to the one"). ${ }^{63}$ Proposition (5) is less easy to identify, but most probably takes up ET 62 ("every multitude which is closer to the one is smaller than the more remote ones in quantity, but greater in power"), which was also part of the Arabic

59 Harmony $\S 56$ (64,7-65,17 B.).

60 Proclus arabus, p. 246, where the claim of verbal agreement of the entire first three propositions goes, however, a little too far. Dieterici refers to the Theology of Aristotle X,9299, where (on the basis of Plotinus, Ennead VI 7, 8,16-32) the different degrees of oneness in the creator, the intellect and the soul are described. Although this passage displays quite a few similarities with the five aforementioned "propositions", it clearly neither contains all of them (especially the first one, the only one which is accompanied by its proof in the Harmony, is entirely absent) nor does it present the relevant thoughts in the form of propositions.

61 Cf. Proclus, The Elements of Theology, A revised text with translation, introduction and commentary by E.R. Dodds, $2^{\text {nd }}$ edn (Oxford, 1963).

62 Endress, Proclus Arabus, p. 3: inna fī kulli kathratin al-wāhìia mawjūdun; cf. Harmony $\S$ 56 (64,16-65,1 B.): al-wāhìidu mawjūdun fī kulli kathratin.

${ }^{63}$ Cf. the Arabic wording (Endress, p. 9): inna kulla kathratin hiya ba'da al-wāhidi, and Harmony $\S 56$ (65,8f): al-kathratu ba'da al-wāhidi lā mahālata. 
corpus. ${ }^{64}$ This proposition culminates in an interesting remark on the relationship between body, soul, intellect and the creator:

Now it becomes clear and evident from what we have said that the corporeal substance is larger in number than the substance of soul, and after the substance of soul there is only the intellectual substance, and the substance of soul is larger in number than the intellectual substance, and after the intellectual substance there is only the first one, i.e. the first cause, which is only one and by no means many. ${ }^{65}$

One could suppose that it was this passage our author referred to, when he continues after enumerating the propositions:

Then, after having established those propositions/premises, he ascends to the statement on the parts of the world, the corporeal and the spiritual of them, and makes sufficiently clear that all of those came to be because of a creative act of their creator, and that he, mighty and great, is the efficient cause, the true one, and creates all things according to what Plato has explained in his books on theology, like the Timaeus, the Politeia and others among the rest of his sayings. ${ }^{66}$

The Kitāb uthūlūjiȳ our author had in hand, was, however, obviously neither identical with the Theology of Aristotle we have nowadays, ${ }^{67}$ nor with the collection of Proclean propositions published by Endress. In the Arabic manuscript tradition, most of the Neoplatonic metaphysical texts where authorized as derived from or even presenting the theology of Aristotle. ${ }^{68}$ Thus, our author most probably had in hand a manuscript containing both Arabic Plotiniana and Procliana, presented in their entirety as Theology of Aristotle. The references to Plato he adduces in the quotation may thus well have been part of the text he is presenting rather than his own addition, which would help explain not only his certainty concerning the harmony of the two sages, but especially his unquestioned ascription of the concept of creatio ex nihilo to Aristotle's theology: This concept is entirely absent not only from the Corpus Aristotelicum including pseudepigraphical works like the De mundo, but also from the Arabic Plotiniana in their present

64 Endress, Proclus arabus, p. 23. The opposition of quantity and power is, just as in the Harmony, missing here, but probably because of a lacuna in the text.

65 Proclus arabus, p. 23,10-13 (Elements of Theology, p. 58,30-32).

66 Harmony $§ 57(65,10-14$ B.).

67 His quotation in Harmony $\S 75$ (74,6-15 B.), however, stems from Theology I, 21-27 resp. Ennead IV 8, 1,1-12 (ed. Badawi, 22f).

68 Also the Proclus-manuscript published by Endress introduces the Proclean text as excerpts of Alexander from the theology of Aristotle (cf. Proclus arabus, pp. 52-8). On the entire corpus of Arabic Procliana cf. now E. Wakelnig, Feder, Tafel, Mensch. Al-'Āmirī's Kitāb al-Fușūl fī l-ma‘̄ālim al-ilāhiya und die arabische Proklos-rezeption im 10. Jh. (Leiden/Boston 2006), pp. $48-73$. 
form, ${ }^{69}$ but it was demonstrably introduced by Christian or Muslim translators into several of the Arabic Procliana. ${ }^{70}$

What remains, is, however, the puzzling question, how our author relates those texts to the authentic metaphysical work of Aristotle, as his continuation is quite ambiguous:

For also in Aristotle's 'letters' on metaphysics, he proceeds exclusively from the necessary and cogent propositions to make clear the unity of the creator (great be his honour) in the book Lambda (XII). Then he descends reverting in a clear explication of what he had pre-established of those premises in order to clarify them comprehensively. And this is among the things in which no one before him had preceded him and nobody after him reached him until our present time. ${ }^{71}$

Martini Bonadeo wants to refer this "descent" or "reversal" to the beginning of the Theology of Aristotle. ${ }^{72}$ Yet, in my opinion, the most natural reading for those strange two sentences would be to take them as a summary of the books of the Metaphysics following XII, i.e. XIII and XIV, which mainly contain Aristotle's attack on the Platonic theory of principles and ideal numbers. The occasion for this attack seems to be given by the closing chapter of book XII, where Aristotle deals with the relationship between reality and the good or the first principle in arguing mainly for two things:

1 The good cannot be part of an original duality of principles from which the entire reality is derived.

2 The good has to be incorporeal, like ideas and numbers, but, unlike those, it also has to be - qua very first principle - in any case only one.

The various criticisms of Platonic and Pythagorean doctrines contained in this passage are afterwords unfolded in the two subsequent books, in book XIII with special regard to the theory of numbers (one and many) and in book XIV ('reverting' to the topic of XII,10) with special regard to the Platonic and Pythagorean dualism. Thus, it is in fact one of Aristotle's core intentions in those books to prove the priority of the one good (his unmoved mover) to every kind of original duality of principles. Our author would then take the last three books of Aristotle's doubtlessly authentic Metaphysics as an endorsement of the "presuppositions" stated in the Arabic Plotiniana and Procliana, i.e. their complicated rejection of any dualism of principles is taken

69 According to Adamson, Arabic Plotinus, p. 145, n. 59 the only hint towards a creatio ex nihilo in the Theology would be VIII,180, which at a closer look turns out to be just an analysis of the eternal generation of the intellect.

70 Cf. Endress, Proclus arabus, pp. 229-33.

71 Harmony $\S 57$ (65,14-17 B.).

72 L'armonia, $204 \mathrm{f}$. 
as a proof for the strict unity of the creator. Yet, could it have entirely escaped our author's attention that those criticisms in Aristotle were directed against Plato himself? Maybe this is exactly why he brings in the possible predecessors: Aristotle stresses several times in the text that every metaphysical attempt before him had proceeded from a duality of principles and was thus doomed to fail (cf. e.g. XII,10 1075a25-28; XIV,1 1087a29f), yet from time to time also hints at the possibility that those attempts might be interpreted in a correct way congruent with his own (XII,10 1075b9f; XIII,1 1076a14-16). Thus, perhaps we can solve the riddle of the strange statement about possible predecessors in interpreting it as a reference to those remarks which our author might have read as Aristotle's tacit acknowledgement of his teacher and predecessor Plato.

\section{CONCLUSION}

After this restricted analysis of a single paragraph from the treatise On the Harmony between the Two Sages we will return to the more fundamental question of how such an attempt could be attributed to al-Fārābī himself and how it relates to the way al-Fārābī's authentic work, first of all the tripartite Attainment of Happiness (sketching in its second and third part the philosophies of Plato and Aristotle) ${ }^{73}$ deals with that problem. The closing statement of the first part that both philosophers "offer one and the same philosophy" may actually, as Rashed supposed, ${ }^{74}$ be an interpolation, as the actual descriptions of the two philosophies have barely anything in common. In fact, Plato's oeuvre is limited to exploring the sociopolitical conditions for realizing true philosophy, whereas Aristotle is depicted as actually developing it: Starting from "a position anterior to that from which Plato had started", ${ }^{75}$ he provides the scientific proof for what Plato had merely explored dialectically, i.e. the nature of human happiness as based in thoroughly grounded theoretical and practical philosophy. That Plato in dialogues like the Meno, Phaedo or Timaeus had also advanced doctrinal philosophical contents, which were contradicted by Aristotle, is just passed over with silence: The Timaeus does not develop a natural philosophy, but only explains the distinctive marks of the philosopher "and what ought to be his rank in this city". ${ }^{76}$ Plato and Aristotle are thus harmonized by consequently

\footnotetext{
${ }^{73}$ Arabic text: Tahsīl al-sa'äda (Hyderabad, 1968); De Platonis philosophia, ed. F. Rosenthal, R. Walzer (London, 1943; repr. Nendeln, 1973); Falsafat Arisțüțālis, ed. M. Mahdi (Beirut, 1961). English translation: Alfarabi's Philosophy of Plato and Aristotle, trans. M. Mahdi, $2^{\text {nd }}$ edn (Ithaca, 1969).

74 "On the authorship", p. 51, n. 21.

${ }^{75}$ Philosophy of Aristotle $\$ 1$ (tr. Mahdi, 59).

76 Philosophy of Plato $\$ 35$ (tr. Mahdi, 66).
} 
restricting Plato's achievements to formal and preparatory considerations about nature and role of the philosopher, whereas it is left to Aristotle to spell out this philosophy materially.

Interestingly enough, this does not entail as much of a breach in the hermeneutical method between al-Fārābī and the Neoplatonists as one would expect. On the contrary, we find al-Fārābī applying the traditional methods for harmonizing Plato with Aristotle to the Aristotelian corpus itself, as al-Fārābī obviously conceives of Aristotle's system in much more Neoplatonic terms than it would be convenient for a 'pure Aristotelian'. ${ }^{77}$ His emanationist rearrangement of Aristotle's philosophy as structured according to the three ontological levels of nature, soul and intellect makes him resort to a peculiar hermeneutical approach: Rather than developping an abstract philosophical system from Aristotle's texts, he presents their sequence quasi as an idealized philosophical biography, the philosopher himself on his way to happiness, ascending via nature, to soul, to intellect and from there to the vision of the first principle. Having established his method of inquiry in the Organon, al-Fārābì's Aristotle first of all, throughout the Physics, inquires nature as such without reference to higher principles, the necessity of which and thus of an entirely different method he, however, realizes in hinting at the unmoved mover at the end of the Physics. ${ }^{78}$ Nevertheless, his subsequent writings on natural philosophy from the De caelo up to the zoological ones proceed in the purely physical method. Confronted with plants and animals he realizes the insufficiency of natural principles and introduces an entirely new one, the soul, which is said to be related to nature as form to matter. ${ }^{79}$ Thus, he proceeds psychologically throughout the De anima and the Parva naturalia, where he - in analogy to Physics VIII, 10 - again anticipates in the course of his psychological studies the necessity of introducing yet another, even higher principle, in his treatment of dreams. ${ }^{80}$ Finally, in focussing on human psychology in particular, ${ }^{81}$ he is again confronted with the insufficiency of 'soul' as explanatory principle and "is forced" 82 to posit yet another, even more fundamental

77 Pace Rashed, "On the authorship", 53,80 e.a. al-Fārābī's debt to the Neoplatonists is comprehensively argued for (yet in considering the Harmony as authentic) by P. Vallat, Fārābi et l'école d'Alexandrie. Des prémisses de la connaissance à la philosophie politique (Paris, 2004).

78 Philosophy of Aristotle $§ 34$ (tr. Mahdi, 103).

79 Philosophy of Aristotle $§ 74$ (tr. Mahdi, 115f).

80 Philosophy of Aristotle $\S 87$ (tr. Mahdi, 121) cf. ibid. 34 (tr. Mahdi, 103).

81 At this point, al-Fārābī obviously neglects the sequence of Aristotle's psychological writings, which of course treat human psychology from the very beginning, for the sake of his scheme of presentation.

82 Philosophy of Aristotle $§ 90$ (ed. Mahdi, 122,8f). The motive of Aristotle "being forced" (cf. also e.g. §61) by the phenomena underlines the "quasi-biographical" or inductive character 
principle: the intellect. Yet, in examining the soul from this new perspective, it turns out that its potential intellect can only be brought to actual intellection of an intellectual form by an active principle always actually containing those forms, the so-called active intellect, with which the soul has to be united, in order to actually grasp intellectual contents.

At this point Aristotle returned once again to investigate those matters that had escaped him, in many of which he now detected the causes of the difficulties. Then he investigated, whether the Active Intellect is also the cause of the existence of nature and natural things and of the soul and animate things. ${ }^{83}$

As the subsequent exposition shows, this 'reversion' for al-Fārābī means more than a simple appendix to De anima III, 4-5 adding to the epistemological functions of the active Intellect his different creative powers. Rather it entails a retractatio of almost the entire natural philosophy from a completely different angle: As natural philosophy finally transcends itself in having to postulate a transcendent principle in order to explain the noblest act of the noblest natural being, the intellectual knowledge of man, it turns out in the end that a theory of nature can only be complete and fully correct within the framework of a metaphysical exposition of nature's intellectual causes. ${ }^{84}$ The hermeneutical potential of this view is just as obvious as its provenance: Especially the treatment of the Categories, in particular the concept of substance, ${ }^{85}$ reveals that al-Fārābī continues the Neoplatonic tradition of limitating the Aristotelian logic and physics to the sublunar world. ${ }^{86} \mathrm{He}$ wants to assign every problematic Aristotelian statement to a different stage on Aristotle's way to knowledge and thus eliminate almost all the tensions not only within the corpus itself but also between some of its texts and its Neoplatonizing reception, i.e., as the author of the Harmony puts it, assign to every Aristotelian claim "the place where it is found, its rank and the discipline from which it comes". ${ }^{87}$ This way, al-Fārābī proves himself an independent and original reader of Aristotle, yet also clearly

of al-Fārābì's presentation, just as the repeated labelling of some of Aristotle's findings as merely provisional (cf. $\S \S 20,66,68,78,97$ ).

83 Mahdi, Philosophy of Plato and Aristotle, p. 128.

84 This probably amounts to the 'deductive Physics' al-Fārābī misses in Aristotle (cf. Rashed, "Al-Fārābī's lost treatise On Changing Beings", pp. 37-44).

85 Philosophy of Aristotle $§ 4$ (tr. Mahdi, 82f) cf. §§ $17 \mathrm{f}$ (tr. Mahdi, 93-6).

86 Cf. esp. ibid., 129 (following a tradition finally going back to Plotinus, Ennead VI 3, on which text cf. R. Thiel, Aristoteles' Kategorienschrift in ihrer antiken Kommentierung [Tübingen, 2004]).

87 Harmony $\S 45$ (58,3f B.). 
indebted to the late-antique Neoplatonic commentators and their contemporary Arabic disciples, like the author of the Harmony, if it is actually inauthentic. After all, after the preceeding study, one might be inclined to ask whether the presented hermeneutical model would not be flexible enough to make many of the differences between the Harmony and the rest of the Farabian corpus, which were put forward to question the former's authenticity, seem less irreconcilable.*

* This article is the revised version of a paper to be presented at the University of Isfahan in April 2010. For many valuable comments regarding its improvement I would like to thank the reviewer of $A S P$. 


\section{APPENDIX: THE RECEPTION OF AMMONIUS' TREATISE ON EFFICIENT AND FINAL CAUSE IN ARISTOTLE IN THE HARMONY.}

\author{
Al-Fārābī, Jam` § 56 \\ (ed. D. Mallet, F. Najjar \\ [Damascus, 1999], p. 131 / \\ ed. C. Martini Bonadeo [Pisa, \\ 2008], p. 64,10-16) \\ wa-qad bayyana ayḍan fī \\ al-samāi al-țabīiyyi anna \\ al-kulla lā yumkinu an yakūna \\ hudūthuhu bi-al-bakhti \\ wa-al-ittifāqi wa-ka-dhālika fī \\ al-samāi wa-al-'ālami. \\ And he clarifies also in the \\ lecture on Physics that the \\ universe can impossibly have \\ come into being by chance and \\ coincidence, just as he does in \\ 'On heaven and earth'. \\ wa-yastadillu ‘alā dhālika \\ bi-al-nizāmi al-badīi alladhī \\ yūjadu li-ajzā'i al-'ālami \\ ba‘dihā ma`a ba'din. \\ And this he infers from the \\ admirable order to be found in \\ the parts of the universe \\ amongst each other.
}

Simplikios, In Phys. VIII,10 267b17-26 (CAG X)

And in the first book of On heaven he claims that neither God nor nature do anything in vain. (1361,19f)

Yet, also in the second book of the lecture on Physics he calls chance and coincidence accidental causes supervening the ones efficient per se, i.e. intellect and nature, and adds: '[. . . ] no matter to what degree coincidence is the cause of this universe, intellect and nature are necessarily causes to a higher, primary degree, both of many other things and of this universe". (1362,20-30) In book I of the Metaphyscis [...], he writes: 'Someone [i.e. Anaxagoras] who claimed the intellect to inhere, just as in animals, also in nature while being the cause of the cosmos and the entire order appeared as widely awake in comparison to the futile babblers before him'. [...] He thus praises those who rank the intellect as final and efficient cause, just as he shortly before praised Anaxagoras, because the latter had kept the intellect unaffected and unmixed in calling it principle of movement.

(1361,33-1362,10) 
wa-qad bayyana hunāka amra al-ilali wa-kam hiya wa-athbata al-illata al-fāiila.

And there he made clear the issue of causes, both how many there are and insofar as he affirms the efficient cause.

wa-qad bayyana ayḍan hunāka amra al-mukawwini wa-al-muharriki

wa-annahu ghayru

al-mukawwani

wa-al-mutaḥarraki,

And there he also clarified the issue of the generator and mover, and that it differs from the entity generated and moved,
Nobody doubts that Aristotle called God final cause or primary mover. Yet, that he also called him efficient cause, is, in my opinion, sufficiently proved by the fact that in the classification of causes in the second book of the lecture on Physics he calls the efficient cause 'where the principle of movement comes from': 'Furthermore is that (a cause) where the first beginning of change or rest comes from, e.g. the man who gave the advice to do something is a cause, the father is cause of the child, and generally what makes of what is made.' How then could it have been put more clearly in order to show that the first mover is an efficient cause? (1361,11-18)

And that the term 'becoming' in Plato and the term 'movement' in Aristotle both mean 'change', can easily be understood from the fact that Plato distinguishes the becoming entity qua changing entity from the one behaving always identically, whereas Aristotle, when he claims every moved entity to be moved by something else, does not only talk about properly moved things, but also about things coming to be and passing away and changing ones in general. Thus, he often called the unmovable unchangeable, as it not only transcends movement properly speaking, but also coming to be and passing away. (1359,30-38)

One has to pay attention to the fact that an entity moved by something else necessarily also has its existence from elsewhere, as substance is more than movement. Yet, if according to Aristotle the power of every limited body is also limited, obviously both the one to move and the one to sustain its own substance, this body necessarily receives, just as it has the eternal movement from an unmoved cause, also the eternal corporeal substance from an incorporeal cause. $(1363,2-8)$ 
wa-kamā anna Aflatūna fĩ kitābihi al-ma'rūfi bi-tīmāwusi bayyana anna kulla mukawwani innamā yatakawwanu 'an 'illatin mukawwinatin lahu iḍtịāran

wa-anna al-mukawwana lā yakūnu 'illatan li-kawni dhātihi.

just as Plato explains in his book known as Timaeus that everything generated necessarily is generated thanks to a cause which generates it, and that the generated thing is not cause of its own generation.
Plato found the creator of the cosmos, the intellective god, in proceeding from the substance of the mundane body itself. In distinguishing therefore the true being from becoming, [...] he ranks the entire corporeal substance as generated and having its being in becoming and being therefore - as incapable of self-generation - dependent upon a cause: 'For it is impossible', he says, 'for any kind of entity to come into being without a cause'. [...] Hence, he discovered the creator of the cosmos as a really existing intellective god, who behaves always identically as established in the Aeon, by proceeding from the changeable substance of the cosmos up to the unchangeable cause. However, also Aristotle ascended from movement and change and the extended and limited existence of bodies up to the unmoved, unchangeable and unextended cause. $(1359,8-26)$ 